\title{
Refractory period, conduction of trains of impulses, and effect of temperature on conduction in chronic hypertrophic neuropathy
}

\author{
Electrophysiological studies on the Trembler mouse
}

\author{
P. A. L O W A N J. G. M C L E O D
}

From the Department of Medicine, University of Sydney, Sydney, Australia

SUMMARY The refractory period, the ability to transmit trains of impulses, and the effect of temperature on conduction, have been studied in the sciatic-tibial nerve trunks of Trembler mice, which suffer from a dominantly inherited hypertrophic neuropathy. Both the refractory period of transmission and the relative refractory period were increased in Trembler mice when compared with controls. The nerve trunks of Trembler mice were unable to conduct rapid trains of impulses, and conduction block occurred at rates of stimulation as low as $25 \mathrm{~Hz}$. Cold block occurred at temperatures significantly higher in Trembler nerves than in controls. The conduction velocity increased in an approximately linear fashion in both Trembler and control nerves when the temperature was raised from $20^{\circ} \mathrm{C}$ to $40^{\circ} \mathrm{C}$, and the slopes were not significantly different. The $\mathrm{Q}_{10}\left(27^{\circ} \mathrm{C}-37^{\circ} \mathrm{C}\right)$ was 1.5 and 1.6 for control and Trembler nerves respectively. Conduction block was regularly observed in Trembler nerves when the temperature was raised within the physiological range. The abnormalities are related to the pathological changes of chronic demyelination.

It is now well established that in experimental demyelination of the reripheral and central nervous system, there is a prolongation of the refractory period and impairment of conduction of trains of impulses (Cragg and Thomas, 1964; McDonald and Sears, 1970; Iehmann and Tackmann, 1970; Lehmann, Lehmann, and Tackmann, 1971; Davis, 1972; Rasminsky and Sears, 1972), and also an abnormal response to temperature change (Davis and Jacobson, 1971; Rasminsky, 1973). However, the investigations have been performed after acute demyelinating lesions, and similar electrophysiological studies have not previously been undertaken in animals with chronic demyelinating disorders. In the present study, the refractory period, the ability to conduct trains of impulses, and the effect of temperature have been examined in the Trembler mouse, which suffers from a dominantly inherited chronic hypertrophic neuropathy (Ayers and Anderson, 1973), and in which

Accepted 2 November 1976 motor conduction velocity in the peripheral nerves does not exceed $6 \mathrm{~m} / \mathrm{s}$ (Low and McLeod, 1975).

\section{Materials and methods}

ANIMALS

The refractory period of the sciatic-tibial nerve was studied in eight control mice and 11 Trembler mice. The age of control animals ranged from 2 to 6 months (mean 3.1; SD, 1.5), and that of Trembler mice ranged from 3 to 6 months (mean, 3.9: SD, 1.5).

The conduction of impulses evoked by stimulus trains was studied in 13 control and 17 Trembler mice. The ages of control mice ranged from 3 to 6 months (mean, 4.0; SD, 0.4), and the ages of Trembler mice ranged from 3 to 12 months (mean, $4.5 ; \mathrm{SD}, 2.3$ ).

The effect of temperature on conduction was examined in the sciatic and tibial nerves of nine control and 10 Trembler mice. The ages of con- 
trol mice ranged from 3 to 6 months (mean, 4.1; $\mathrm{SD}, 1.2$ ), and those of Trembler mice also ranged from 3 to 6 months (mean, 4.1; SD, 1.5).

\section{ELECTROPHYSIOLOGICAL TECHNIQUES}

Anaesthesia was induced with intraperitoneal pentobarbitone $(50 \mathrm{mg} / \mathrm{kg})$, and maintained with halothane inhalation when necessary. The lower limbs and lower half of the trunk were shaved, after which the sciatic and posterior tibial nerves were exposed in the thigh and tibial regions respectively, under a dissecting microscope. The sciatic nerve was cut at the proximal end of the thigh wound and its branches were also sectioned, care being taken to preserve the blood supply of the nerve. The animal was stretched out on a cork and perspex board and its lower half immersed, hind feet first, into a perspex box containing liquid paraffin (Fig. 1). The temperature of the bath was monitored by a thermistor probe which was suspended between the stimulating and recording electrodes, and, at a more distant site, by a mercury thermometer. For studies of

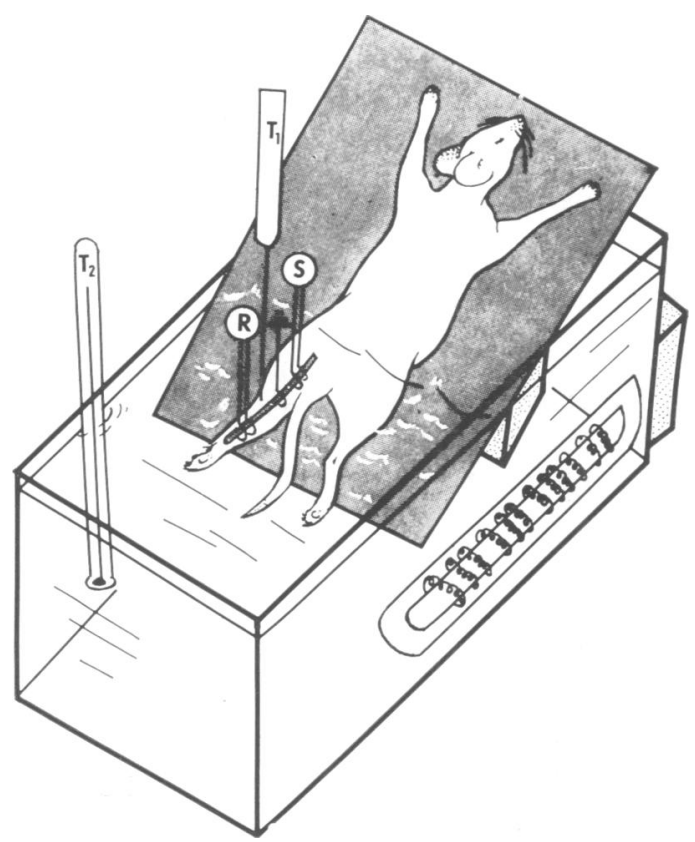

Fig. 1 Experimental arrangement for nerve trunk recordings. Nerve trunk is immersed in liquid paraffin contained in perspex box. Temperature is thermostatically controlled. $T 1$ and $T 2$ represent thermistor probe and mercury thermometer respectively. $S$ and $R$ represent stimulating and recording electrodes. refractory period and conduction of trains of impulses, the temperature of the bath was maintained at $37^{\circ} \mathrm{C}$ by a thermostatically controlled heating device, and the paraffin was circulated by means of a magnetic stirrer. The proximal part of the sciatic nerve was stimulated through paired silver electrodes. Recording electrodes were paired silver wire electrodes with an interelectrode distance of $1 \mathrm{~cm}$ which were placed under the posterior tibial nerve. The distance between stimulating and recording electrodes was measured by means of a divider to the nearest $\mathrm{mm}$ and ranged from 15 to $22 \mathrm{~mm}$. The action potential recorded in this way was usually diphasic or triphasic. Recordings of monophasic action potentials were also made after the posterior tibial nerve had been crushed distal to the proximal recording electrode. The stimulus was derived from a Devices stimulator and was a square wave of duration $0.1 \mathrm{~ms}$ for most experiments, but occasionally $0.2 \mathrm{~ms}$ was required to obtain supramaximal stimulation of some Trembler sciatic nerves. The stimulus intensity was set at twice that required to evoke a maximal response. The recording electrodes were connected to a Tektronix FM 122 preamplifier, and the evoked compound nerve action potentials were displayed on the upper beam of a Tektronix 502A oscilloscope. A time scale derived from the time mark generator of a Digitimer (Devices Ltd.) was displayed on the lower beam. Measurements were made on photographic records taken on $35 \mathrm{~mm}$ film.

MEASUREMENT OF THE REFRACTORY PERIOD

The response to a test shock was obtained at different intervals from 0 to $20 \mathrm{~ms}$ after a conditioning shock. The conditioning and test stimuli were of equal intensity.

For both conditioning and test responses, the latency was measured from the stimulus artefact to the first negative deflection of the action potential, and the amplitude of the nerve action potential was measured peak-to-peak on diphasic recordings, and from baseline to peak with monophasic potentials. The measurements were made after photographic enlargement $(\times 6-10)$ of $35 \mathrm{~mm}$ film.

The compound nerve action potential recorded from Trembler nerve was dispersed, and considerable difficulty was encountered in the measurements of latencies and amplitudes of the test and conditioning responses. Particular difficulties occurred in identifying the components of the waveform after the test stimulus at short interstimulus intervals. In order to identify such components, the waveform after a single conditioning 
shock was subtracted from that following the test shock when preceded by the conditioning shock.

Several seconds were allowed to elapse between stimulus pairs when they were delivered to Trembler nerve trunks in order to avoid conduction block which occurred at higher repetition rates.

The refractory period of transmission (RPT) was defined as that interval at which the test response was just discernible. The relative refractory period (RRP) was determined using two methods:

1. Amplitude method, RRP (A): The RRP was defined as the minimum interval at which the amplitude of the test response was equal to that of the conditioning response.

2. Latency method, RRP (L): The latency from the stimulus artefact to the onset of the conditioning and test response was measured at increasing interstimulus intervals. The RRP (L) was the time taken for the test latency to return to normal.

\section{TRAINS OF IMPULSES}

Brief trains of 10 to 20 stimuli of twice-maximal intensity were delivered at the following stimulus frequencies to nerves of control and Trembler mice: $10 \mathrm{~Hz}, 25 \mathrm{~Hz}, 50 \mathrm{~Hz}, 100 \mathrm{~Hz}, 200 \mathrm{~Hz}$, $400 \mathrm{~Hz}, 500 \mathrm{~Hz}$.

The number of pulses and stimulus frequencies was determined by the setting of a gated pulse generator (Devices Ltd.). The temperature was maintained at $37^{\circ} \mathrm{C}$. The effects of long lasting subnormality were avoided by using short stimulus trains and by allowing two minutes to elapse between successive trains. Peak-to-peak amplitudes of the first 10 action potentials in the train were measured after enlargement, $\times 6-10$.

\section{EFFECT OF TEMPERATURE}

Experiments were begun with the initial temperature of the bath at $0^{\circ} \mathrm{C}$, after which it was raised in small steps. Each temperature recording was made only after the thermistor reading had remained steady for 30 to 60 seconds. The temperature of the bath was raised until conduction block occurred or until a temperature of at least $45^{\circ} \mathrm{C}$ was reached. In order to ensure a uniform temperature, the temperature was raised in small steps, and the paraffin bath was continuously stirred. The adequacy of the stirring action was checked by comparing the thermistor reading with that of the distant thermometer. With adequate stirring the temperature did not differ by more than $0.5^{\circ} \mathrm{C}$. The thermistor tip was maintained at approximately $1.0 \mathrm{~mm}$ from the nerve.
The following measurements were made on the recorded action potentials after they had been magnified $\times 6-10$.

(a) The latency, measured from stimulus artefact to onset of the first negative deflection.

(b) Peak-to-peak amplitude of the compound nerve action potential when diphasic recordings were made.

(c) The area of the monophasic compound nerve action potential above the isoelectric line. The outline was traced on graph paper, and the area under the curve was measured with a planimeter. The accuracy of the reading was checked by counting the number of squares on the graph paper within the waveform.

\section{Results}

THE REFRACTORY PERIOD OF TRANSMISSION (RPT) (FIGS. 2, 3)

The RPT of control animals ranged from 0.6 to $0.9 \mathrm{~ms}$ (mean, 0.7; SD, 0.1). By contrast, the RPT for Trembler nerves ranged from 1.5 to $5.0 \mathrm{~ms}$ (mean, 2.3; SD, 1.0), and in every instance fell outside the control range.

RELATIVE REFRACTORY PERIOD (FIGS. 2-5)

The RRP (A) ranged from 2.5 to $6.0 \mathrm{~ms}$ (mean, 3.0; SD, 1.3) for control mice (Fig. 3) while that of Trembler mice was significantly longer $(\mathrm{P}<0.001)$ ranging from 4.5 to $20 \mathrm{~ms}$ (mean, 9.7; $\mathrm{SD}, 4.3)$.

The RRP (L) ranged from 2.0 to $4.5 \mathrm{~ms}$ (mean, 3.1; SD, 0.8) for control mice (Fig. 3), and ranged from 5 to $16 \mathrm{~ms}$ (mean, 9.2; SD, 3.2) for Trembler mice. The results obtained using amplitude and latency methods of measuring RRP were not significantly different $(\mathrm{P}>0.05)$.

In control nerves the amplitude of the test response exceeded that of the conditioning responses after $6 \mathrm{~ms}$. No supernormal period was found in Trembler nerves.

THE EFFECT OF TRAINS OF IMPULSES ON CONDUCTION The ratio of the amplitude of the tenth response to that of the first was expressed as a percentage. The ratio in Trembler mice was less than that of control mice at all stimulus frequencies (Figs. 6, 7; Table 1).

At a stimulation rate of $100 \mathrm{~Hz}$ the mean amplitude of the tenth response for Tremblers was reduced to $56.9 \%$ of the first response (SD, 18.9). By contrast the mean ratio for control mice was $93.6 \%$ (SD, 12.0). The difference is highly significant $(\mathrm{P}<0.001)$.

At a stimulus frequency of $200 \mathrm{~Hz}$, the mean 


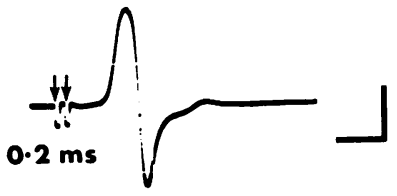

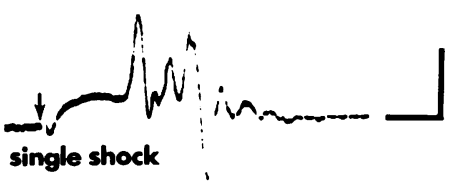<smiles>CCCCCCCCCCCCC(C)(C)O</smiles>

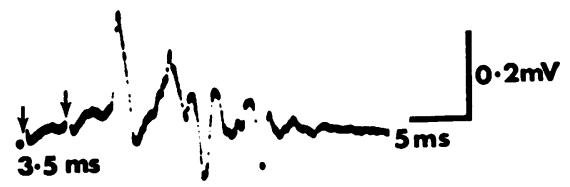

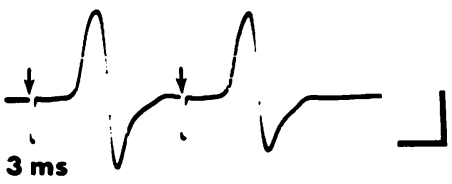

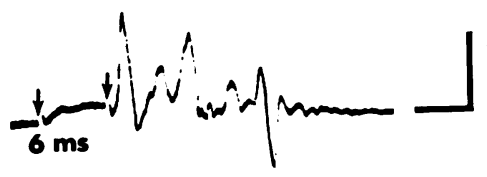

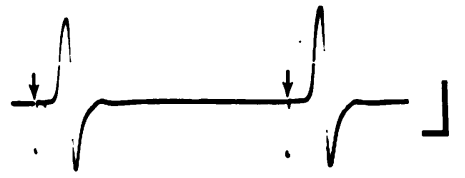

$10 \mathrm{~ms}$

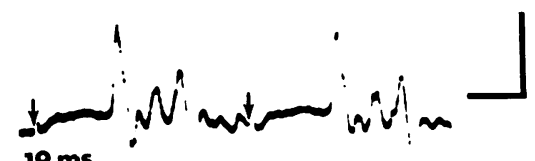

Fig. 2 Conditioning and test responses following paired stimuli (arrows) of control (left column) and Trembler (right column) nerves.
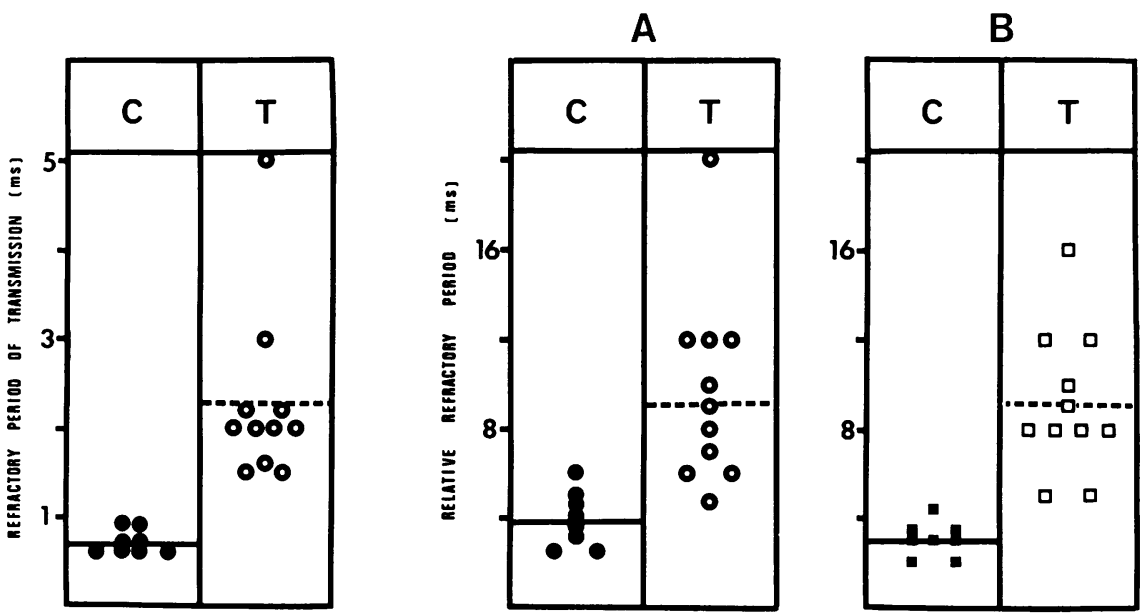

Fig. 3 Refractory period of transmission and relative refractory period of control (C) and Trembler (T) nerves. Results in A have been obtained using amplitude measurements and in $B$, latency measurements. 

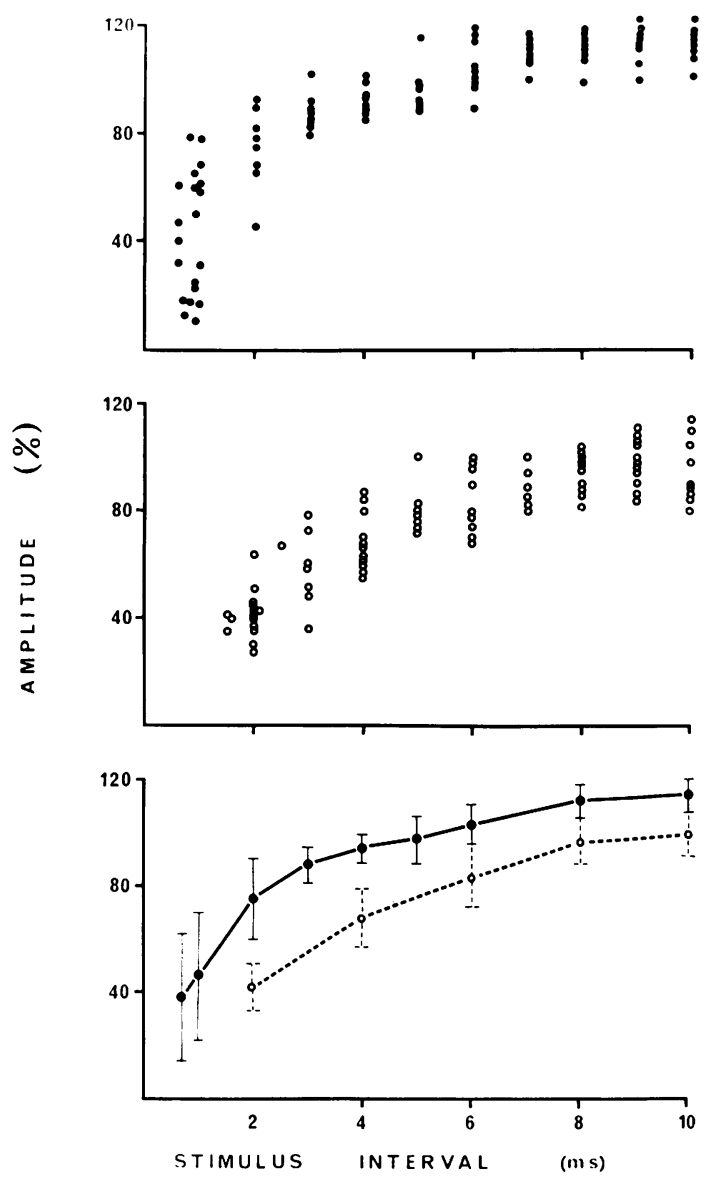

Fig. 4 Amplitude of test response expressed as a percentage of conditioning response for control (closed circles) and Trembler (open circles) nerves. Result of individual experiments are shown in upper two graphs, and means and $S D$ of pooled data in bottom graph.

ratio for Trembler mice was only $28.7 \%$ (SD, 12.0 ), which is markedly more reduced than that of control mice $(83.3 \%, \mathrm{SD}, 16.6)$. The difference is highly significant $(P<0.001)$ (Table 1$)$.

In order to study in greater detail this decremental response, the ratio of the amplitudes of the second through to the tenth response, taken as a percentage of the first, was measured in seven control and eight Trembler mice. It may be seen from Fig. 8 that there is a progressive decrease in amplitude of the second through to the tenth response in Trembler mice at stimulus frequencies exceeding $10 \mathrm{~Hz}$ and in control mice at frequencies above $25 \mathrm{~Hz}$.
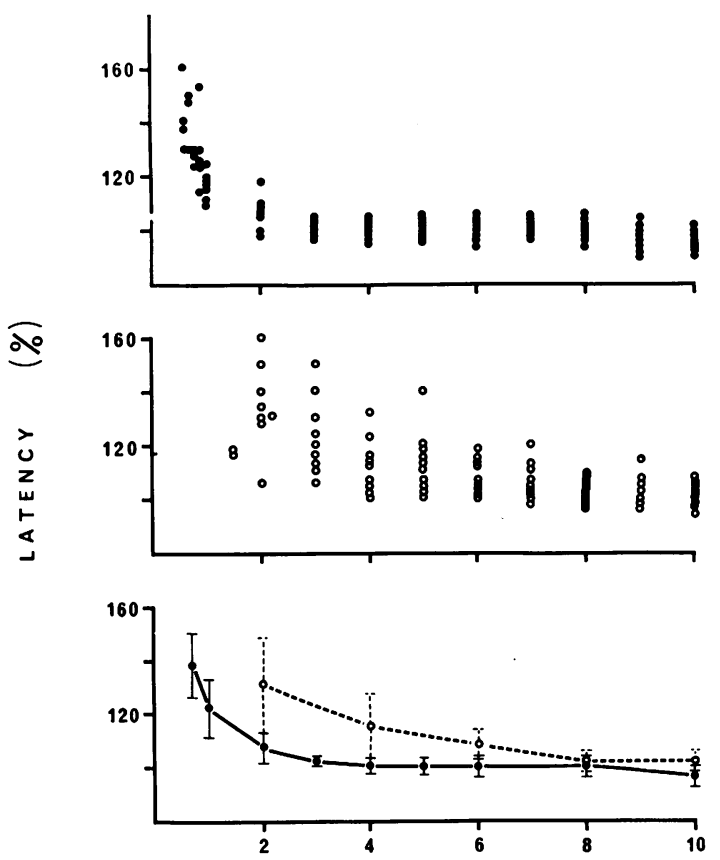

STIMULUS INTERVAL (ms)

Fig. 5 Latency of test response expressed as a percentage of conditioning response for control (closed circles) and Trembler (open circles) nerves. Results of individual experiments are shown in upper two graphs, and means and SD of pooled data in bottom graph.

COLD BLOCK (FIG. 9; TABLE 2)

The blocking temperature was examined in six control and 10 Trembler nerves. The blocking temperature in control mice ranged from $5^{\circ}$ to $8^{\circ} \mathrm{C}$ (mean, 6.5; SD, 1.0) while that in Trembler mice ranged from $5^{\circ}$ to $16^{\circ} \mathrm{C}$ (mean, 9.2; SD, 3.4). The difference is significant $(P<0.05)$. Blocking occurred in six of the 10 Trembler nerves at temperatures which fell outside the control range.

THE EFFECT OF CHANGE OF TEMPERATURE ON CONDUCTION VELOCITY

Conduction in six of nine control and six of 10 Trembler nerve preparations was studied over an extensive temperature range from $0^{\circ} \mathrm{C}$ to at least $45^{\circ} \mathrm{C}$ or until warm block occurred. In the remaining animals, studies were conducted over a more limited temperature range.

With an increase in temperature the threshold, latency, and action potential duration progressively decreased. The threshold of Trembler nerves was higher than control nerves at all temperatures. 

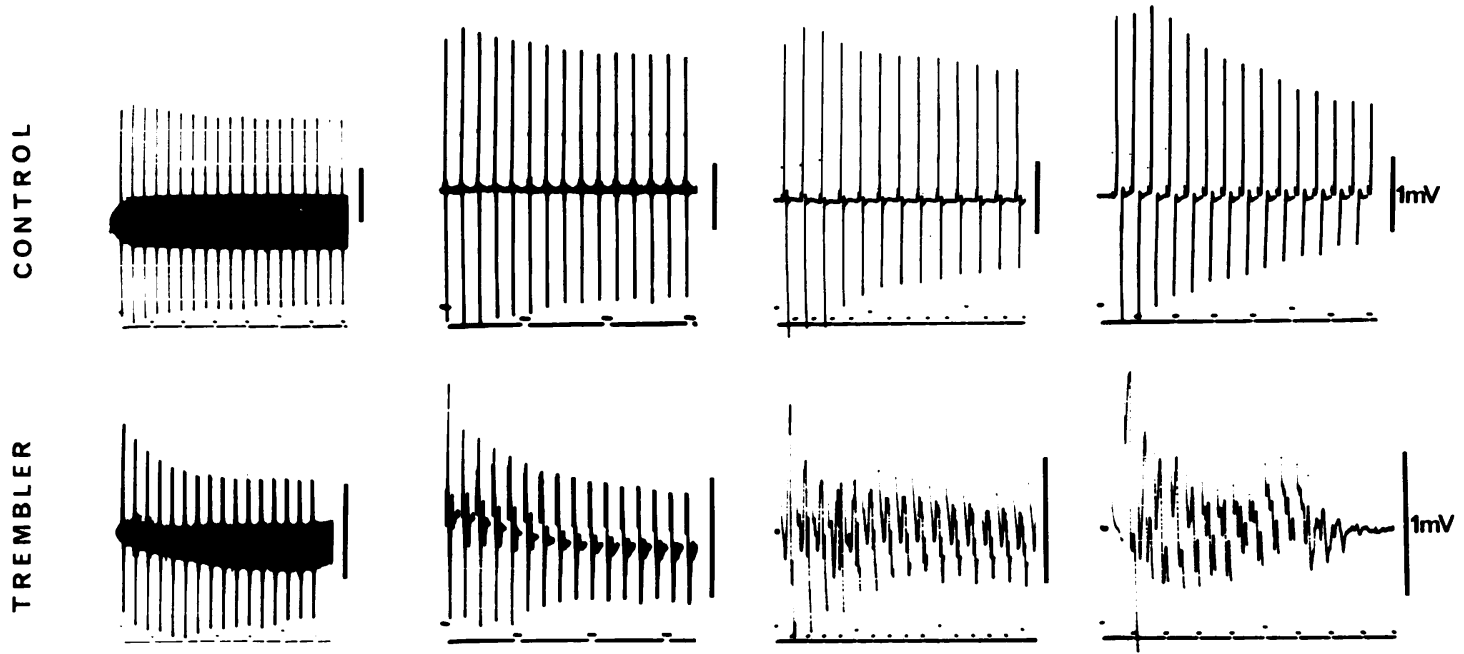

$25 \mathrm{H}_{\mathrm{z}}$

$50 \mathrm{H}_{\mathrm{z}}$

$100 \mathrm{H}_{\mathbf{z}}$

$200 \mathrm{H}_{\mathrm{z}}$

Fig. 6 Effect of trains of impulses on amplitude of compound nerve action potential of sciatic-tibial nerves of control and Trembler mice.

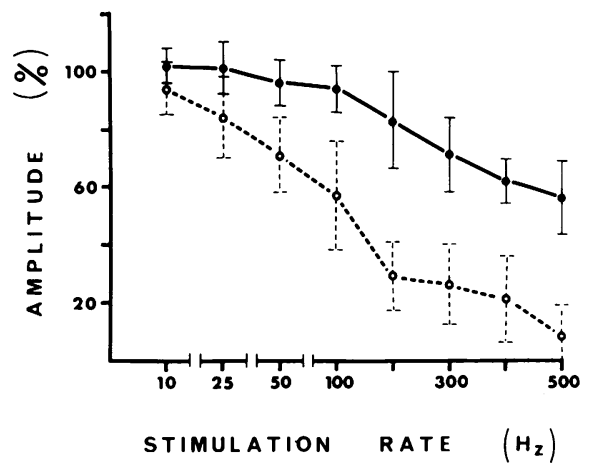

Fig. 7 Mean amplitude (\%) of compound nerve action potential of the tenth response relative to the first in control (closed circle) and Trembler (open circle) sciatic-tibial nerve. Bars represent $2 S D$.

The amplitude of the action potential of control and Trembler nerves progressively increased as the temperature was gradually raised to $30^{\circ} \mathrm{C}$ (Fig. 10). Above $30^{\circ} \mathrm{C}$ the amplitude of control action potentials underwent only minor variations up to $40^{\circ} \mathrm{C}$ and above this a gradual decline occurred (Figs. 10, 11; Table 3). By contrast, a progressive reduction in action potential amplitude was seen in Trembler mice above $30^{\circ} \mathrm{C}$ (Fig. 11; Table 3 ). The conduction velocity

$$
\text { ( } \left.\frac{\text { conduction distance }}{\text { latency }}\right)
$$

Table 1 Comparison of the effect of trains of impulses on the sciatic-tibial nerves of control and Trembler mice

Amplitude of tenth/amplitude of first response (\%)

\begin{tabular}{lllll}
\hline $\begin{array}{l}\text { Stimulus } \\
\text { frequency } \\
(\mathrm{Hz})\end{array}$ & $\begin{array}{l}\text { Control } \\
\%\end{array}$ & $\begin{array}{l}\text { Trembler } \\
\%\end{array}$ & $\begin{array}{l}\text { Degrees of } \\
\text { freedom }\end{array}$ & $\begin{array}{l}\text { Significance } \\
\text { of difference }\end{array}$ \\
\hline 10 & $101.8 \pm 5.7$ & $93.5 \pm 9.0$ & 29 & $\mathrm{P}<0.01$ \\
25 & $101.3 \pm 8.8$ & $83.6 \pm 14.6$ & 29 & $\mathrm{P}<0.001$ \\
50 & $96.4 \pm 8.1$ & $71.5 \pm 13.3$ & 28 & $\mathrm{P}<0.001$ \\
100 & $93.6 \pm 12.0$ & $56.9 \pm 18.9$ & 24 & $\mathrm{P}<0.001$ \\
200 & $83.3 \pm 16.6$ & $28.7 \pm 12.0$ & 17 & $\mathrm{P}<0.001$ \\
300 & $70.6 \pm 13.4$ & $25.7 \pm 14.4$ & 15 & $\mathrm{P}<0.001$ \\
400 & $61.5 \pm 7.9$ & $20.7 \pm 15.0$ & 12 & $\mathrm{P}<0.001$ \\
500 & $56.1 \pm 13.2$ & $8.1 \pm 11.4$ & 10 & $\mathrm{P}<0.001$ \\
\hline
\end{tabular}

Means are expressed with standard deviation.

at each temperature was expressed as a percentage of that recorded at $37^{\circ} \mathrm{C}$. There was a progressive increase in conduction velocity in both control and Trembler preparations as the temperature was raised (Fig. 12). When the conduction velocity was plotted against temperature the relationship was approximately linear from $20^{\circ}$ to $40^{\circ} \mathrm{C}$. The curves of both control and Trembler nerves tended to flatten out at the extremes of temperature, and in particular at the lower temperature range.

The relationship of conduction velocity to changes in temperature between $20^{\circ} \mathrm{C}$ and $40^{\circ} \mathrm{C}$ was examined further. The grouped data of control and Trembler mice fitted a linear regression 

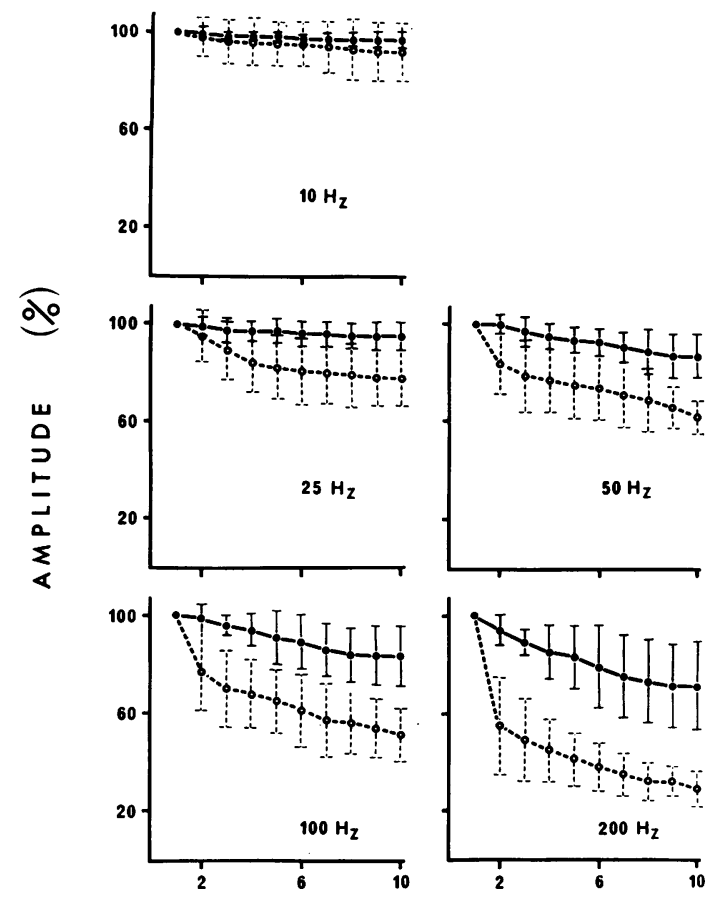

RESPONSE NUMBER

Fig. 8 Mean amplitude (\%) of the second through to the tenth response relative to the first in control (closed circle) and Trembler (open circle) sciatic-tibial nerve. Bars represent $2 S D$.

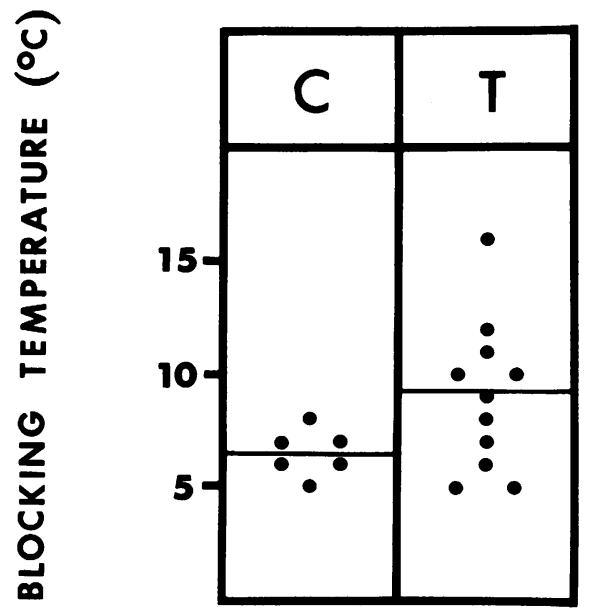

Fig. 9 Cold blocking temperature of control $(C)$ and Trembler $(T)$ nerves.
Table 2 Effect of temperature change on conduction velocity in the sciatic-tibial nerves of control and Trembler mice.

Linear regression analysis on grouped data

\begin{tabular}{|c|c|c|}
\hline & Control & Trembler \\
\hline $\begin{array}{l}\text { Number of animals } \\
\text { Number of measurements } \\
\text { Regression equation } \\
\text { slope } \\
\text { correlation coefficient } \\
\text { significance of slope }\end{array}$ & $\begin{array}{l}\mathbf{9} \\
\mathbf{8 8}=3.685 \mathrm{x} \\
-44.495 \\
3.685 \\
0.837 \\
P<0.001\end{array}$ & $\begin{array}{l}10 \\
96 \\
Y=3.247 x \\
-22.124 \\
3.247 \\
0.878 \\
P<0.001\end{array}$ \\
\hline Difference between slopes & NS & \\
\hline $\begin{array}{l}\text { Gradient }\left(\% /{ }^{\circ} \mathrm{C}\right) \\
\mathrm{Q}_{10}\left(37^{\circ} \mathrm{C}-27^{\circ} \mathrm{C}\right) \\
\text { Cold block } \\
\text { Number of animals } \\
\text { range }\left({ }^{\circ} \mathrm{C}\right) \\
\text { mean } \\
\text { SD }\end{array}$ & $\begin{array}{l}6 \\
5-8 \\
6.5 \\
1.0\end{array}$ & $\begin{array}{l}10 \\
5-16 \\
9.2 \\
3.4\end{array}$ \\
\hline Significance of difference & $P<0.05$ & \\
\hline $\begin{array}{l}\text { Minimum velocity (\%) } \\
\text { Number of animals } \\
\text { range } \\
\text { mean } \\
\text { SD }\end{array}$ & $\begin{array}{l}6 \\
11.5-32 \\
17.7 \\
7.6\end{array}$ & $\begin{array}{l}10 \\
17.2-34.4 \\
27.8 \\
6.7\end{array}$ \\
\hline Significance of difference & $\mathrm{P}<0.05$ & \\
\hline
\end{tabular}

line with a high degree of significance (control $\mathrm{P}<0.001, \mathrm{R}=0.837$; Trembler $\mathrm{P}<0.001, \mathrm{R}=0.878$; Table 2). The difference of the two slopes was not significant which indicates that the velocities of Trembler and control nerves tended to be affected to a similar degree by temperature alterations. The velocity of control nerves changed by $3.7 \%$ per ${ }^{\circ} \mathrm{C}$ alteration in temperature, and that of Trembler mice by $3.2 \%$ per ${ }^{\circ} \mathrm{C}$. Expressed as temperature coefficients, the $\mathrm{Q}_{10}\left(27-37^{\circ} \mathrm{C}\right)$ are 1.6 and 1.5 for control and Trembler mice respectively.

The minimum conduction velocity (Table 2) that is, the velocity before conduction blockin control mice ranged from $11.5 \%$ to $32 \%$ of that at $37^{\circ} \mathrm{C}$ (mean, 17.7; SD, 7.6) which may be compared with that of Trembler nerves which ranged from $17.2 \%$ to $34.4 \%$ (mean, 27.8; SD, 6.7). The difference is significant $(\mathrm{P}<0.05)$.

WARM BLOCK

When the temperature was raised from $30^{\circ} \mathrm{C}$ to $45^{\circ} \mathrm{C}$, the amplitude of the compound nerve action potential in control nerves underwent only minor changes (Fig. 11). By contrast, the amplitude in most Trembler nerves became markedly reduced when the temperature of the bath was raised beyond $35^{\circ} \mathrm{C}$, which indicates that conduction block 

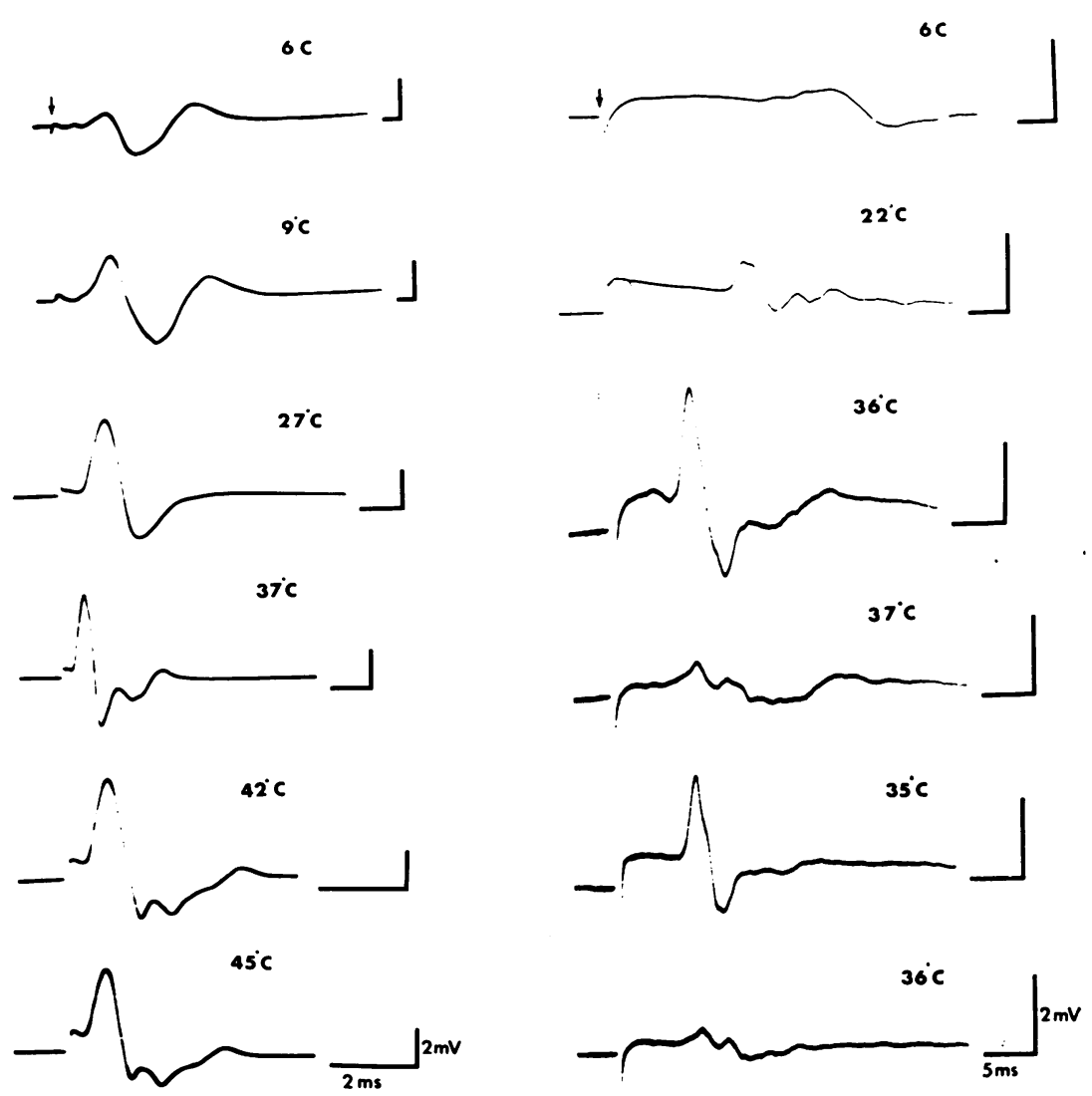

Fig. 10 Diphasic compound nerve action potential of control (left column) and Trembler (right column) sciatic-tibial nerve in response to temperature change.

had occurred in many fibres. Conduction block sometimes occurred with minor alterations in temperature. It may be seen from Fig. 10 that when the temperature was raised from $36^{\circ} \mathrm{C}$ to $37^{\circ} \mathrm{C}$, a marked decrease in amplitude occurred, which was reversed when the temperature was lowered to $35^{\circ} \mathrm{C}$; when the temperature was raised again, the marked decrease recurred, this time at $36^{\circ} \mathrm{C}$

In order to examine the occurrence of warm block in the faster conducting fibres when the temperature of the nerve preparation was raised, the amplitude of the biphasic compound nerve action potential was measured at each of the temperatures, $30^{\circ} \mathrm{C}, 35^{\circ} \mathrm{C}, 37^{\circ} \mathrm{C}, 40^{\circ} \mathrm{C}$, and $45^{\circ} \mathrm{C}$, and expressed as a percentage of that recorded at $37^{\circ} \mathrm{C}$. These measurements were made on the sciatic-tibial nerves of seven control and seven Trembler mice (Fig. 11; Table 3). The mean amplitude at $40^{\circ} \mathrm{C}$ was only $40.7 \%(\mathrm{SD}, 29.5)$ in Tremblers, which is significantly lower $(\mathrm{P}<0.01)$ than that in controls (mean, 98\%, SD, 3.2). At $45^{\circ} \mathrm{C}$, the mean amplitude in controls was $85.7 \%$ (SD, 8.6), while all Tremblers had unrecordable action potentials. These findings indicate that marked conduction block occurs in Trembler mice when the temperature is raised above $37^{\circ} \mathrm{C}$. At $30^{\circ} \mathrm{C}$ the mean amplitude in control nerves was $83.2 \%$ (SD, 25.0), while that of Tremblers was markedly $(\mathrm{P}<0.001)$ greater $(294.4 \%$; $\mathrm{SD}$, 107.9). The finding indicates that at $37^{\circ} \mathrm{C}$ there is already a considerable degree of conduction block in Trembler nerves.

In addition to the amplitude measurements made on diphasic recordings, studies were also performed on monophasic recordings obtained after crushing the nerve trunk beneath the distal recording electrodes. The area of the monophasic compound nerve action potential was measured in two control and three Trembler nerves (Figs. 13, 14). The area in Trembler nerves became progressively smaller as the temperature was raised 


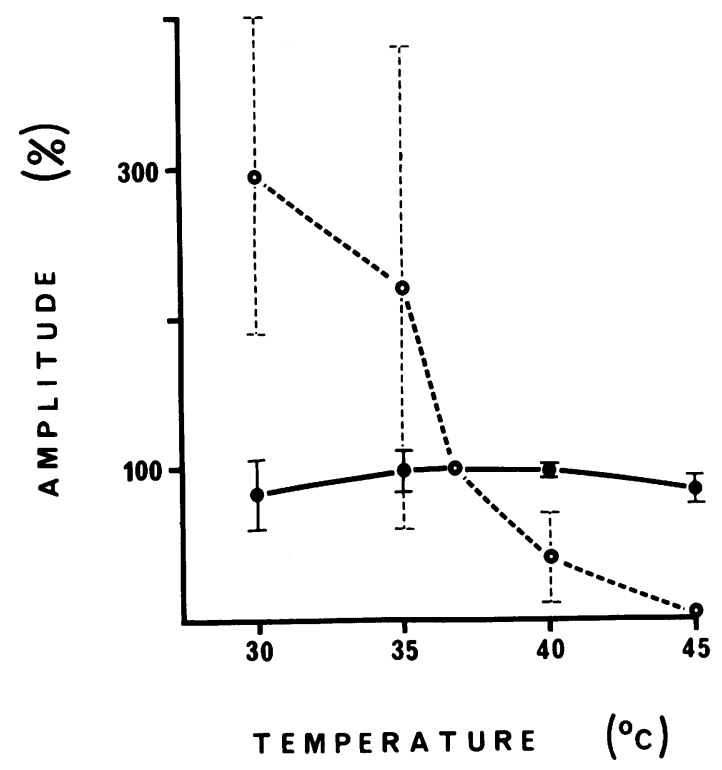

Fig. 11 Mean amplitude (\%) of compound nerve action potential relative to that at $37^{\circ} \mathrm{C}$ for control (closed circle) and Trembler (open circle) sciatic-tibial nerves. Bars represent $2 S D$.

Table 3 Comparison of the effect of temperature change on conduction in the sciatic-tibial nerves of control and Trembler mice

\begin{tabular}{llcll}
\hline \multirow{2}{*}{$\begin{array}{l}\text { Temperature } \\
{ }^{\circ} \mathrm{C}\end{array}$} & Amplitude $(\%)^{*}$ & $\begin{array}{c}\text { Degrees of } \\
\text { freedom }\end{array}$ & $\begin{array}{l}\text { Significance } \\
\text { of difference }\end{array}$ \\
\cline { 2 - 5 } & Control & Trembler & & \\
\hline 30 & $83.2 \pm 25.0$ & $294.4 \pm 107.9$ & 12 & $\mathrm{P}<0.001$ \\
35 & $97.6 \pm 13.8$ & $221.4 \pm 162.3$ & 11 & NS \\
40 & $98 \pm \pm 3.2$ & $40.7 \pm 29.5$ & 13 & $\mathrm{P}<0.001$ \\
45 & $85.7 \pm 8.6$ & 0 & 13 & $\mathrm{P}<0.001$ \\
\hline
\end{tabular}

*Amplitude at each temperature is represented as $\%$ of amplitude at $37^{\circ} \mathrm{C}$ (mean $\left.\pm \mathrm{SD}\right)$.

above $30^{\circ} \mathrm{C}$, and was markedly reduced or absent by $40^{\circ} \mathrm{C}$, while the action potential areas of control nerves underwent little change. These findings confirm the presence of the conduction block which had been demonstrated in the amplitude studies.

\section{Discussion}

The term 'refractory period of transmission' (RPT), used by McDonald and Sears (1970), was preferred to absolute refractory period when referring to the least interval at which a response to a second stimulus could be recorded.

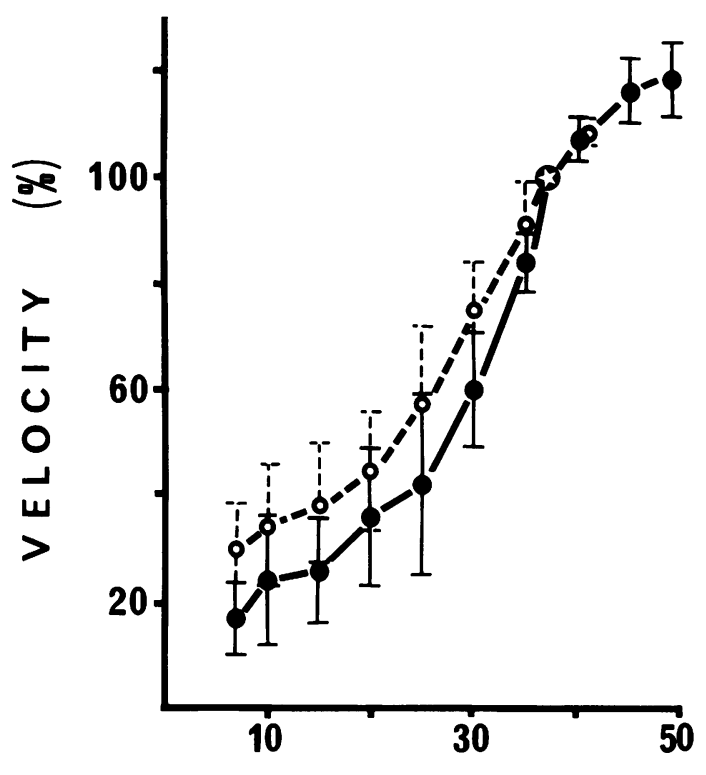

TEMPERATURE ( $\left.{ }^{\circ} \mathrm{C}\right)$

Fig. 12 Effect of temperature change on mean conduction velocity relative to that at $37^{\circ} \mathrm{C}$ in contro (closed circle) and Trembler (open circle) sciatic-tibial nerves. Bars represent $2 S D$, and star. $37^{\circ} \mathrm{C}$.

Paintal (1965b) has shown that the RPT inversely proportional to the conduction velocity of nerve fibres. In the present investigation, the mean value for RPT of $0.7 \mathrm{~ms}$ with a range of $0.6-0.9 \mathrm{~ms}$ in control mice is in general agreement with that of other studies on mammalian nerve trunks in which the RPT of the fastest conducting fibres has been measured (Gasser and Grundfest, 1936; Hursh, 1939; Birren and Wall, 1956; Kiraly and Krnjević, 1959).

In the present study on a chronic demyelinating neuropathy, the RPT fell outside the control range in all the Trembler mice, and the RRP was also prolonged. The RPT and RRP are also consistently abnormal in acute experimental demyelinating neuropathies (Lehmann and Pretschner, 1966; Lehmann, Tackmann and Lehmann, 1971; Lehmann, Lehmann and Tackmann, 1971). In $\bigcirc$ their studies on single fibres, Rasminsky and Sears (1972) confirmed that RPT was increased in acute demyelination.

The findings of the present study also show that $\sigma$ in the chronic demyelinating neuropathy of the $N$ Trembler mouse there is an inability to transmit rapid trains of impulses. Cragg and Thomas (1964) 

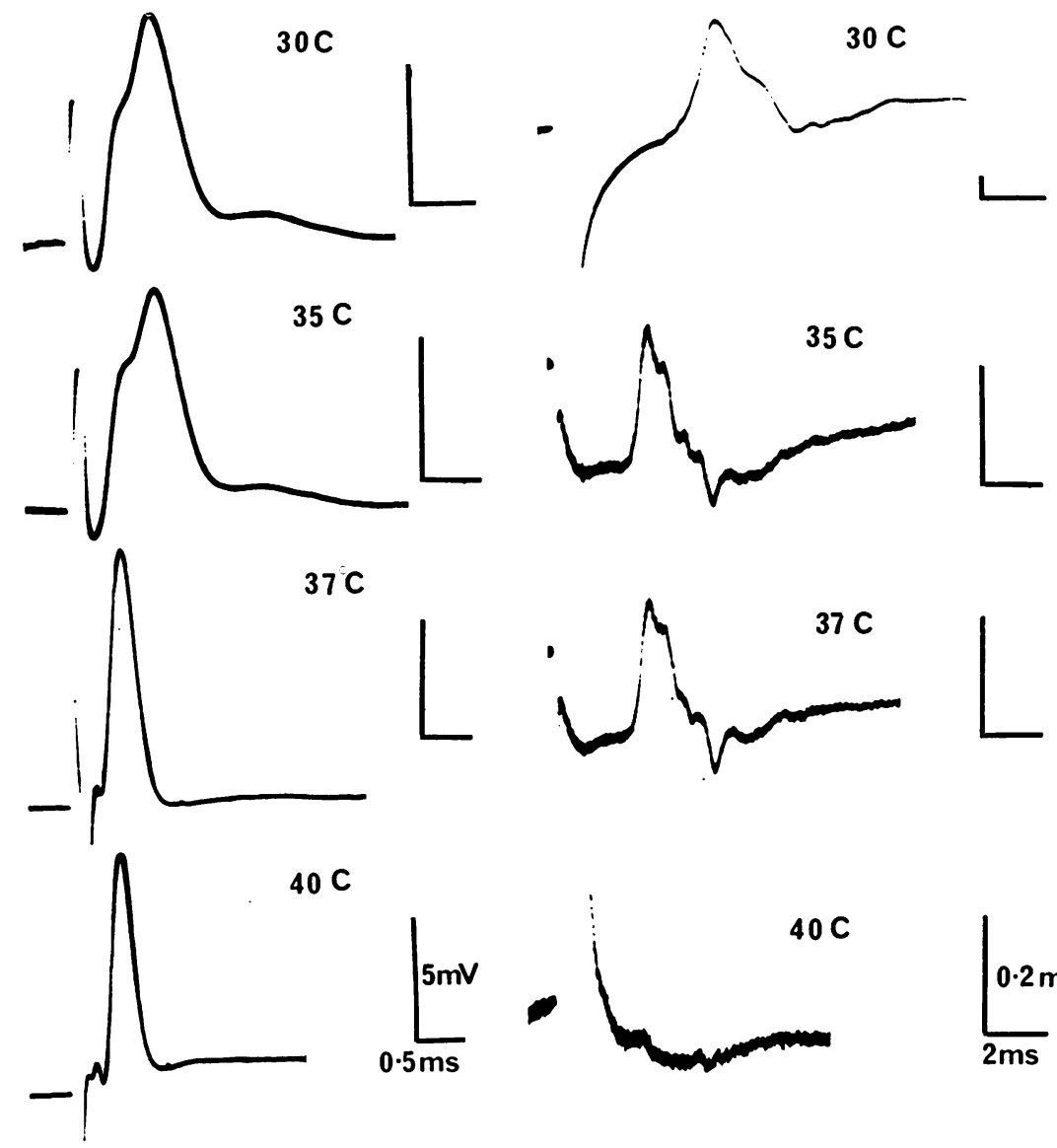

$40 \mathrm{C}$

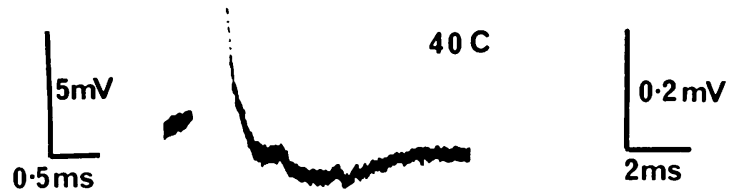

Fig. 13 Monophasic compound nerve action potentials of control (left column) and Trembler (right column) sciatic-tibial nerve in response to temperature change.

found that in the severely affected nerves of guinea pigs with experimental allergic neuritis there was impairment of the transmission of rapid trains of impulses. Davis (1972) noted decrement in the amplitude of the action potential with repetitive stimuli in guinea pigs with experimental allergic neuritis at stimulation rates as low as 10 to $25 \mathrm{~Hz}$, and noted similar findings in pressureinjured frog sciatic nerves. This inability of demyelinated fibres to transmit rapid trains of impulses was also demonstrated on single fibres by Rasminsky and Sears (1972), who, in a study of diphtheria-induced demyelination in rat ventral root, showed that with continued repetitive stimulation internodal conduction time increased progressively until conduction block ensued.

There has been considerable discussion about the relationship between refractory period and the maximum rate at which trains of impulses are conducted. Paintal (1965b, 1966, 1973) demonstrated in single nerve fibres that the least interval between the first two impulses depends on the absolute refractory period and the conduction velocity of a myelinated fibre. The effect of impulses falling in the relative refractory period would explain the abrupt amplitude change in Trembler mice between the first and second response at stimulation rates of 100 to $200 \mathrm{~Hz}$ and the smaller decrease at $50 \mathrm{~Hz}$. An abnormal fibre with an RRP of $20 \mathrm{~ms}$ (RRP of Trembler mice is 4.5 to $20 \mathrm{~ms}$ ) would be unable to conduct impulses above $50 \mathrm{~Hz}$ without decrement in its amplitude. However, from the studies of Paintal (1973) further decrement in the amplitude of the third and subsequent responses would not be expected.

The progressive and gradual amplitude decrement which affects Trembler nerves at stimulation 


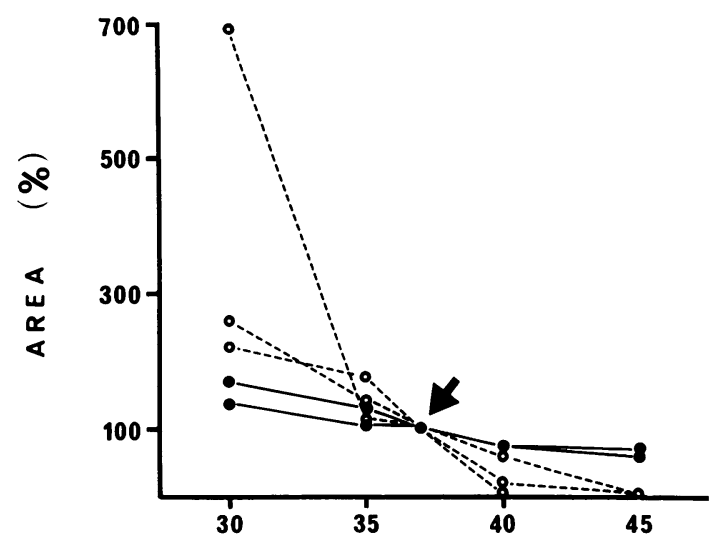

TEMPER AT URE $\left({ }^{\circ} \mathrm{C}\right)$

Fig. 14 Area (\%) of monophasic compound nerve action potential relative to that at $37^{\circ} \mathrm{C}$ of control (closed circle) and Trembler (open circle) sciatic-tibial nerves. Arrow indicates $37^{\circ} \mathrm{C}$.

rates above $10 \mathrm{~Hz}$ and control nerves at rates of stimulation of $50 \mathrm{~Hz}$ may be attributed to subnormality following a tetanus (Gasser, 1935; Gasser and Grundfest, 1936; Bergmans, 1973).

The inability of nerve fibres in the Trembler mouse to conduct rapid trains of impulses is of physiological importance since high frequency discharges occur in normal sensory nerves in animals (Hunt and McIntyre, 1960a,b) and man (Hensel and Boman, 1960). In human chronic demyelinating neuropathies, such as hypertrophic Charcot-Marie-Tooth disease and chronic relapsing neuropathy, the impairment of conduction of high frequency discharges may contribute to the motor and sensory symptoms. Similar abnormalities in demyelinated central nerve fibres in patients with multiple sclerosis may cause some visual and sensory disturbances and the rapid increase of muscle weakness during exercise (McDonald, 1974).

In the studies of the effect of temperature on conduction, the whole nerve trunk was immersed in a paraffin bath of a uniform temperature so that no temperature interface or kinking occurred (Paintal, 1965b; Franz and Iggo, 1968). The temperature of the nerve was monitored by a thermistor which was situated midway between stimulating and recording electrodes.

The findings confirm the results of previous workers who noted a linear relationship between temperature and conduction velocity (Gasser, 1931; Birren and Wall, 1956; Kiraly and Krnjević
1959; Paintal, 1965a,b; Franz and Iggo, 1968; Hopkins and Gilliatt, 1971; Rasminsky, 1973).

In the present study, the curve relating velocity to temperature was flatter at lower temperatures than those published by other workers. This difference is probably the result of the technique of cooling the nerves to $0^{\circ} \mathrm{C}$ and then slowly rewarming the preparation. The slight flattening at the lower temperature is probably due to hysteresis (Paintal, 1965a,b; Franz and Iggo, 1968), since when an axon is warmed after cold block, conduction resumes at a higher temperature and velocity than those measured just before cold block, and the curve relating velocity to temperature may be initially flatter (Franz and Iggo, 1968). It is possible that hysteresis is more pronounced in demyelinated nerves, and may be one reason why the minimal temperature and cold blocking temperatures are higher, and the curve flatter in Trembler preparations.

The mean blocking temperature in control nerves of $6.5^{\circ} \mathrm{C}$ agrees well with that of Franz and Iggo (1968) who recorded a mean blocking temperature of $7.3^{\circ} \mathrm{C}$ in myelinated fibres of cafl or saphenous nerve. Paintal (1965a) found a slightlo higher blocking temperature of $7.6^{\circ} \mathrm{C}$ in my $\stackrel{\omega}{\perp}$ elinated fibres of cat vagus and $9.1^{\circ} \mathrm{C}$ in those of cat saphenous nerve. The present values are i close agreement with those of Byck et al. (1972 and Basbaum (1973) who reported values of $5.3^{\circ}$ and $5.0^{\circ} \mathrm{C}$ respectively in their studies on ca saphenous and sciatic nerves.

The mechanism of cold block was considered by Tasaki and Fugita (1948), Tasaki (1949), Paintal (1965a), and Franz and Iggo (1968). Conduction at low temperature is presumed to fail because reduced action currents are insufficient to overcome the greatly raised threshold at the adjacent node. The threshold is increased when normal nerve is cooled (Tasaki and Fugita, 1948; Tasaki, 1949; Davis and Jacobson, 1971), and was much increased in Trembler nerves when compared to control nerves which were cooled to a similar degree. Demyelinated nerves have an increased internodal capacitance and internodal transverse conductance (Rasminsky and Sears, 1972); this results in shunting of current and delayed excitation of the adjacent node. When the already reduced action current is further reduced by cooling the nerve, conduction block may ensue at a higher temperature in demyelinated than in control nerves.

The conduction velocity between $20^{\circ}$ and $40^{\circ} \mathrm{C}$ changed by $3.7 \%$ and $3.2 \%$ per ${ }^{\circ} \mathrm{C}$ in controls and Trembler nerves, which corresfond to $Q_{10}$ values of 1.6 and 1.5 respectively. These values fall well 
within the range obtained by previous reports based on studies in man and other animals (Birren and Wall, 1956; Henriksen, 1956; Paintal, 1965a,b; Franz and Iggo, 1968; Hopkins and Gilliatt, 1971).

The findings of warm block at physiological temperatures in the Trembler mouse confirm, in a chronic and naturally occurring neuropathy, the relationship between demyelination and temperature-dependent block of conduction which has been demonstrated in acute demyelination (Davis and Jacobson, 1971; Rasminsky, 1973). Rasminsky (1973), working with rat ventral root fibres that had been demyelinated by the microinjection of diphtheria toxin, showed that conduction block may occur when the temperature is raised by as little as $0.5^{\circ} \mathrm{C}$ within the physiological range. A similar abrupt block occurred in the present study.

Demyelinated central fibres behave similarly to demyelinated peripheral fibres (McDonald, 1974). It is likely that warm block occurs in demyelinated central fibres and that it explains the symptoms and signs that may occur in multiple sclerosis when the temperature is raised (Nelson and McDowell, 1959), and the clinical improvement when the temperature is lowered (Watson, 1959). Howcver, it is paradoxical that the clinical evidence of warm block and cold unblock has not been described in human demyelinating neuropathies when the peripheral nerve trunks undergo greater temperature changes than those of the central myelinated fibre tracts. Rasminsky and Sears (1972) showed that the abnormalities of conduction were due mainly to the increased myelin capacitance and conductance, and warm block was predicted by their computer model which has been based on these findings (Koles and Rasminsky, 1972). Although the precise mechanism for warm block is not clear, it seems likely that warming further reduces the safety factor which has already been impaired by acute demyelination (Davis and Jacobson, 1971; Rasminsky, 1973).

It is not known whether the mode of conduction in Trembler nerves is saltatory or continuous. Rasminsky and Sears (1972) showed that single ventral root fibres of the rat which had been demyelinated by the focal application of diphtheria toxin continued to conduct in a saltatory fashion up to the point of block. The computer models of Smith and Koles (1970) predicted that saltatory conduction would ccase when myelin was reduced to 5-6\%, and that of Koles and Rasminsky (1972) when it was reduced to $3.5 \%$ of normal. These figures are equivalent to $10-12$ and five lamellae respectively, assuming that one internode is affected. In the Trembler nerves all fibres were seen to be severely affected on teased fibre exam- ination, and on electron microscopy severe hypomyelination was present with a mean thickness of five turns of myelin, and on longitudinal sections no normal nodes of Ranvier were seen; there were numerous areas of uncompact myelin which would have greatly increased internodal transverse conductance (Low, 1976). There does not appear, therefore, to be the necessary morphological prerequisite for saltatory conduction to occur.

Smith and Koles (1970) predicted that saltatory conduction ceased when the velocity was reduced to $20 \%$ of normal. The motor conduction velocity in Trembler mice (less than $6 \mathrm{~m} / \mathrm{s}$ ) was less than $10 \%$ of control values (Low and McLeod, 1975). Slowing of this degree has also been recorded through the amyelinated roots of dystrophic mice (Huizar et al., 1975), and in Dejerine-Sottas neuropathy in man (Dyck, 1966).

The relationship between conduction velocity and fibre diameter in unmyelinated fibres has been found to be linear by Gasser (1950) and Hodes (1953), and to vary approximately with the square root of the diameter by Pumphrey and Young (1938). The velocities found in Trembler nerves fall within the range expected if the fibres were assumed to be unmyelinated.

Unmyelinated fibres have refractory periods of about $2 \mathrm{~ms}$ (Gasser, 1950), are unable to conduct rapid trains of impulses (Iggo, 1960; Torebjörk and Hallin, 1974), undergo abrupt conduction block on warming (Gasser, 1950; Davis, 1970), and have a higher threshold of excitation (Gasser, 1950). All these features resemble those in the peripheral nerves of the Trembler mouse in which single fibre studies, similar to those of Huxley and Stämpfli (1949) and Rasminsky and Sears (1972), will be necessary to determine finally whether conduction is saltatory or continuous.

Dr. Low was a Roche Research Fellow of the Royal Australasian College of Physicians. This work was supported by grants from the National Health and Medical Research Council of Australia, and from the Postgraduate Medical Foundation, University of Sydney.

\section{References}

Ayers, M. M., and Anderson, R. McD. (1973). A model of hypertrophic interstitial neuropathy (Dejerine-Sottas) in man. Acta Neuropathologica (Berlin), 25, 54-70.

Basbaum, C. B. (1973). Induced hypothermia in peripheral nerve: electron microscopic and electrophysiological observations. Journal of Neurocytology, 2, 171-187.

Bergmans, J. (1973). Physiological observations on 
single human nerve fibres. In New Developments in Electroinyography and Clinical Neurophysiology. Vol. 2, p. 91. Edited by J. E. Desmedt. Karger: Basel.

Birren, J. E., and Wall, P. K. (1956). Age changes in conduction velocity, refractory period, number of fibers, connective tissue space and blood vessels in sciatic nerve of rats. Journal of Comparative Neuro$\log y, 104,1-16$.

Byck, R., Goldfard, J., Schaumburg, H. H., and Sharpless, S. K. (1972). Reversible differential block of saphenous nerve by cold. Journal of Physiology, 222, 17-26.

Cragg, B. G., and Thomas, P. K. (1964). Changes in nerve conduction in experimental allergic neuritis. Journal of Neurology, Neurosurgery, and Psychiatry, 27, 106-115.

Davis, F. A. (1970). Axonal conduction studies based on some considerations of temperature effects in multiple sclerosis. Electroencephalography and Clinical Neurophysiology, 28, 281-286.

Davis, F. A. (1972). Impairment of repetitive impulse conduction in experimentally demyelinated and pressure-injured nerves. Journal of Neurology, Neurosurgery, and Psychiatry, 35, 537-544.

Davis, F. A., and Jacobson, S. (1971). Altered thermal sensitivity in injured and demyelinated nerve: a possible model of temperature effects in multiple sclerosis. Journal of Neurology, Neurosurgery, and Psychiatry, 34, 551-561.

Dyck, P. J. (1966). Histologic measurements and fine structure of bicpsied sural nerve: normal, and in peroneal muscular atrophy, hypertrophic neuropathy, and congenital sensory neuropathy. Mayo Clinic Proceedings, 41, 742-774.

Franz, D. N., and Iggo, A. (1968). Conduction failure in myelinated and nonmyelinated axons at low temperatures. Journal of Physiology, 199, 319-345.

Gasser, H. S. (1931). Nerve activity as modified by temperature changes. American Journal of Physiology, 97, 254-270.

Gasser, H. S. (1935). Changes in nerve potentials produced by rapidly repeated stimuli and their relation to the responsiveness of nerve to stimulation. American Journal of Physiology, 111, 35-50.

Gasser, H. S. (1950). Unmdullated fibers originating in dorsal root ganglia. Journal of General Physiology, 33, 651-690.

Gasser, H. S., and Grundfest, H. (1936). Action and excitability in mammalian A fibers. American Journal of Physiology, 117, 113-133.

Henriksen, J. D. (1956). Conduction velocity of motor nerves in normal subjects and patients with neuromuscular disorders. MS (Phys. Med.) Thesis, University of Minnesota.

Hensel, H., and Bcman, K. K. A. (1960). Afferent impulses in cutaneous sensory nerves in human subjects. Journal of Neurophysiology, 23, 564-578.

Hodes, R. (1953). Linear relationship between fiber diameter and velocity of conduction in giant axon of squid. Journal of Neurophysiology, 16, 145-154.

Hopkins, A., and Gilliatt, R. W. (1971). Motor and sensory nerve conduction velocity in the baboon: normal values and changes in acrylamide neuropathy. Journal of Neurology, Neurosurgery, and Psychiatry, 34, 415-426.

Huizar, P., Huno, M., and Miyata, Y. (1975). Electrophysiological properties of spinal motor neurones of normal and dystrophic mice. Journal of Physiology, 248, 231-246.

Hunt, C. C., and McIntyre, A. K. (1960a). Characteristics of responses from receptors from the flexor longus digitorum muscle and the adjoining interosseous region of the cat. Journal of Physiology, 153, 74-87.

Hunt, C. C., and McIntyre, A. K. (1960b). An analysis of fibre diameter and discharge characteristics of myelinated cutaneous afferent fibres in cat. Journal of Physiology, 153, 99-112.

Hursh, J. B. (1939). Conduction velocity and diameter of nerve fibers. American Journal of Physiology, 127, 131-139.

Huxlöy, A. F., and Stämpfli, R. (1949). Evidence for saltatory conduction in peripheral myelinated nerve fibres. Journal of Physiology, 108, 315-339.

Iggo, A. (1960). Cutaneous mechanoreceptors with afferent C fibres. Journal of Physiology, 152, 337353.

Kiraly, J. K., and Krnjević, K. (1959). Some retrograde changes in function of nerves after peripheral section. Quarterly Journal of Experimental Physiology, 44, 244-257.

Koles, Z. J., and Rasminsky, M. (1972). A computer simulation of conduction in demyelinated nerve fibres. Journal of Physiology, 227, 351-364.

Lehmann, H. J., Lehmann, G., and Tackmann, W. (1971). Refraktär periode und Übermittlung von Serien impulsen im N. tibialis des Meerschweinchens bei experimenteller allergischer Neuritis. Zeitschrift für Neurologie, 199, 67-85.

Lehmann, H. J., and Pretschner, D. P. (1966). Experimentalle Untersuchungen zum Engpassyndrom peripherer Nerven. Deutsche Zeitschrift für Nervenheilkunde, 188, 308-330.

Lehmann, H. J., and Tackmann, W. (1970). Die Übermittlung frequenter Impulsserien in demyelinisierten und indegenerierenden Nervenfasern. Archiv für Psychiatrie und Nervenkrankheiten (Berlin), 213, 215-277.

Lehmann, H. J., Tackmann, W., and Lehmann, G. (1971). Funktionsänderung markhaltiger Nervenfasern im $N$. tibialis des Meerschweinchens bei postdiphtherischer Polyneuritis. Zeitschrift für Neurologie, 199, 86-104.

Lov, P. A. (1976). Hereditary hypertrophic neuropathy in the Trembler mouse. II. Histopathological studies: electron microscopy. Journal of the Neurological Sciences, 30, 343-368.

Low, P. A., and McLeod, J. G. (1975). Hereditary demyelinating neuropathy in the Trembler mous:. Journal of the Neurological Sciences, 26, 566-574.

McDonald, W. I. (1974). Pathophysiology in multiple sclerosis. Brain, 97, 179-196.

McDonald, W. I., and Sears, T. A. (1970). The effects 
of experimental demyelination on conduction in the central nervous system. Brain, 93, 583-598.

Nelson, D. A., and McDowell, F. (1959). The effects of induced hyperthermia on patients with multiple sclerosis. Journal of Neurology, Neurosurgery, and Psychiatry, 22, 113-116.

Paintal, A. S. (1965a). Block of conduction in mammalian myelinated nerve fibres by low temperatures. Journal of Physiology, 180, 1-19.

Paintal, A. S. (1965b). Effects of temperature on conduction in single vagal and saphenous myelinated fibres of the cat. Journal of Physiology, 180, 20-49.

Paintal, A. S. (1966). The influence of diameter of medullated nerve fibres of cats on the rising and falling phases of the spike and its recovery. Journal of Physiology, 184, 791-811.

Paintal, A. S. (1973). Conduction in mammalian nerve fibres. In New Developments in Electromyography and Clinical Neurophysiology. Vol. 2, pp. 19-41. Edited by J. E. Desmedt. Karger: Basel.

Pumphrey, R. J., and Ycung, J. Z. (1938). The rates of conduction of nerve fibres of various diameters in cephalopods. Journal of Experimental Biology, 15, 453-466.

Rasminsky. M. (1973). The effects of temperature on conduction in demyelinated single nerve fibers. Archives of Neurology (Chicago), 28, 287-292.

Rasminsky, M., and Sears, T. A. (1972). Internodal conduction in undissected demyelinated nerve fibres. Journal of Physiology, 117, 323-350.

Smith, R. S., and Koles, Z. J. (1970). Myelinated nerve fibers: computed effect of myelin thickness on conduction velocity. American Journal of Physiology, 219, 1256-1258.

Tasaki, I. (1949). The excitatory and recovery processes in the nerve fibre as modified by temperature changes. Biochemica et Biophysica Acta, 3, 498509.

Tasaki, I., and Fugita, M. (1948). Action currents of single nerve fibers as modified by temperature change. Journal of Neurophysiology, 11, 311-315.

Torebjörk, H. E., and Hallin, R. G. (1974). Response of human $\mathrm{A}$ and $\mathrm{C}$ fibres to repetitive electrical intradermal stimulation. Journal of Neurology. Neurosurgery, and Psychiatry, 37, 653-664.

Watson, C. W. (1959). Effect of lowering of body temperature on the symptoms and signs of multiple sclerosis. New England Journal of Medicine, 261, 1253-1259. 